\title{
Faktor - Faktor Yang Berhubungan Dengan Pelaksanaan Tugas Kader Kesehatan Dalam Kegiatan Posyandu
}

\author{
Fitri Aprianti \\ STIKESMAS Abdi Nusa Palembang \\ email : fitriaprianti806@yahoo.com
}

\begin{abstract}
Abstrak
Kata Kunci: : Posyandu, pelaksanaan tugas kader, pengetahuan kader

Keywords: Posyandu, implementati on of cadres' duties, cadre knowledge.

Info Artikel: Tanggal dikirim: 7

Juli 2019

Tanggal direvisi: 23

Juli 2019

Tanggal diterima: 23 Juli 2019 DOI Artikel: 10.33862/cit radelima.v3i 1.64 Halaman: 37- 42

Kesehatan merupakan masalah yang penting dalam sebuah keluarga, terutama yang berhubungan dengan bayi, balita dan ibu hamil. Kota Bandar Lampung tahun 2009 memiliki 602 unit Posyandu yang terdiri dari Posyandu Pratama sebesar 147 (24,4\%) ,Madya sebesar 218 (36,2\%), Purnama sebesar 218 (36,2\%) dan mandiri sebesar 19 (3,2\%). Tujuan penelitian adalah diketahui faktor-faktor yang berhubungan dengan pelaksanaan tugas kader kesehatan dalam kegiatan Posyandu di Wilayah kerja puskesmas Sukamaju Teluk Betung Barat Bandar Lampung tahun 2011.

Jenis penelitian kuantitatif. Rancangan penelitian analitik dengan menggunakan pendekatan cross sectional. Populasi adalah seluruh kader Posyandu sebesar 85 Kader.Besar sampel menggunakan total populasi.Analisis data menggunakan chi square.

Hasil penelitian didapat pelaksanaan tugas kader lebih tingi pada kategori kurang baik sebesar 48 orang $(56,5 \%)$, pendidikan kader lebih tinggi pada kategori rendah sebesar 53 orang $(62,4 \%)$, pelatihan kader lebih tinggi pada kategori tidak pernah sebesar 57 orang $(62,4 \%)$ dan pengetahuan kader lebih tinggi pada kategori kurang baik sebesar 56 orang $(65,9 \%)$. Hasil uji chi square didapat ada hubungan bermakna antara pendidikan dengan Pelaksanaan tugaskader Posyandu ( $\mathrm{p}$ value $<\alpha, 0,012<0,05$ ), ada hubungan yang bermakna antara pengetahuan dengan Pelaksanaan tugas kader Posyandu ( $\mathrm{p}$ value $<\alpha, \quad 0,000<$ $0,05)$ dan ada hubungan yang bermakna antara pelatihan dengan Pelaksanaan tugas kader Posyandu ( $\mathrm{p}$ value $<\alpha, 0,0030,05$ ). Diharapkan hasil penelitian ini dapat menjadi masukan bagi petugas kesehatan dalam meningkatkan tugas kader dengan memperhatikan latar belakang pendidikan terutama pendidikan rendah dalam penyampaian informasi dan konsep baru agar kader mudah memahami.

Abstract

Health is an important problem in a family, especially those related to babies, children and pregnant women. In 2009, Bandar Lampung city had 602 Posyandu consisting of 147 (24,4\%) Posyandu Pratama, 218 (36,2\%) Posyandu Madya, 218 (36,2\%) Posyandu Purnama, and 19 (3,25) Posyandu Mandiri. The aim of this study is to determine the factors related to the implementation of health cadres' duties in Posyandu activities in the working area of Sukamaju Teluk Betung Barat health center, Bandar Lampung in 2011. This is a quantitative research. The research design is analytical research design using cross sectional approach. The population is all Posyandu cadres in the amount of 85 cadres. The sample size uses the total population. Data analysis uses chi square.The results show that the implementation of cadres'dutiesis higher in poor category of 48 people $(56.5 \%)$, cadres education is higher in low category of 53 people $(62.4 \%)$, cadres training is higher in never category of 57 people $(62.4 \%)$ and cadres knowledge is higher in poor category of 56 people $(65.9 \%)$. The results of chi square test show that there is a significant correlation between education and the implementation of Posyandu cadres ( $p$ value $<\alpha$, $0.012<0.05$ ), there is a significant correlation between knowledge with the implementation of Posyandu cadres'duties ( $\mathrm{p}$ value $<\alpha, 0,000<0.05$ ) and there is a significant correlation between training and the implementation of Posyandu cadres' duties ( $p$ value $<\alpha, 0.0030 .05$ ). It is expected that the results of this study can be input for health workers in improving cadres' duties with due regard to educational background, especially low education in conveying information and new concepts for cadres easily understand.
\end{abstract}

\section{PENDAHULUAN}

Kesehatan merupakan masalah yang penting dalam sebuah keluarga, terutama yang berhubungan dengan bayi, Balita dan ibu hamil. Oleh karena itu, bayi dan balita merupakan prioritas pertama yang harus dijaga kesehatannya karena dengan kondisi imunitas 
yang masih lemah ia sudah harus menghadapi berbagai virus, bakteri dan berbagai bibit penyakit sudah siap menerjang masuk ke tubuh yang menyebabkan infeksi dan bersifat membahayakan yang pada akhirnya mengganggu fungsi normal tubuh dan dapat berakibat pada luka kronik, gangren, kehilangan organ tubuh bahkan kematian (Wijaya, 2005).

Menurut WHO (World Health Organization) tahun 2007 kematian maternal, neonatal dan balita merupakan masalah global terutama dinegara berkembang.Sekitar 13 juta neonatal di dunia meninggal setiap tahun, lebih dari 2 juta Balita meninggal akibat pneumonia atau sama dengan 4 Balita meninggal setiap menitnya dan hampir 500.000 kematian maternal setiap tahunnya (Depkes

2009).

Strategi nasional bagi upaya penurunan kematian bayi dan balita salah satunya adalah pemberdayaan kesehatan berbasis masyarakat.Upaya menggerakkan masyarakat dalam keterpaduan ini digunakan pendekatan melalui pembangunan Kesehatan Masyarakat Desa (PKMD) yang pelaksanaanya secara operasional dibentuklah Pos Pelayanan Terpadu (posyandu).Posyandu ini merupakan bentuk operasional dan keterpaduan dimana terdapat pertemuan antara pelayanan profesional (tenaga kesehatan) dan non profesional (kader) yang diselenggarakan atas usaha masyarakat (swakelola masyarakat) (Depkes RI, 2004).

Kader merupakan relawan yang berasal dari masyarakat yang mempunyai peranan besar dalam penyampaian informasi kesehatan kepada masyarakat.Kader-kader posyandu pada umumnya adalah relawan yang berasal dari tokoh masyarakat yang dipandang memiliki kemampuan lebih dibanding anggota masyarakat lainnya. Namun keberadaan kader relatif labil karena partisipasinya

bersifat sukarela sehingga tidak ada jaminan bahwa para kader akan tetap menjalankan fungsinya dengan baik seperti yang diharapkan. Pada beberapa tahun terakhir ini, tingkat kinerja dan partisipasi kader posyandu dirasakan menurun yang bisa dilihat dari keaktifan kader, persentase kader aktif nasional adalah $69,2 \%$ dan kader drop out sebesar 30,8\% (Yoel, 2007).

Menurut Depkes (2006) faktor determinan keaktifan kader posyandu adalah tingkat pendidikan, tingkat pengetahuan serta keikutsertaan dalam pelatihan. Masalah Kader Posyandu dapat dilihat dari hasil survei yang dilakukan oleh Universitas Andalas, Universitas Hasanudin dan Sekolah Tinggi Ilmu Gizi pada tahun 2009 mencatat hanya $30 \%$ kader yang terlatih. Selain itu sebahagian besar kader posyandu memiliki pendidikan kategori rendah sebesar $45 \%$ dan pengetahuan kader tentang kegiatan posyandu sangatlah rendah yaitu masih dibawah $50 \%$.

Indikator keaktifan kader dalam kegiatan penyelenggaraan posyandu secara teori aspek paling dominan adalah strata/tingkat kemandirian posyandu.(Depkes, 2006). Di Provinsi Lampung dan Kota Bandar Lampung prosentase strata Posyandu dalam kategori mandiri yang ditandai oleh sudah dapat melaksanakan kegiatan lebih dari 8 kali per tahun dengan rata-rata kader aktif 5 (lima) orang atau lebih, cakupan dari kegiatan utamanya $>50 \%$ masih rendah. Data dinas Kesehatan Provinsi Lampung tahun 2009 memiliki 7.626 Posyandu yang terdiri dari Posyandu Pratama sebesar $786 \quad(10,3 \%)$, Madya sebesar 3.407 (44,7\%), Purnama sebesar $2.934(38,5 \%)$ dan mandiri sebesar 499 $(6,5 \%)$.

Bandar Lampung tahun 2009 memiliki 602 unit Posyandu yang terdiri dari Posyandu Pratama sebesar 147 (24,4\%), Madya sebesar 218 (36,2\%), Purnama sebesar $218(36,2 \%)$ dan mandiri sebesar 19 (3,2\%) (Buku Saku Dinas Kesehatan Provinsi Lampung, 2009).

Kegiatan Posyandu di Wilayah Kerja Puskesmas Sukamaju secara umum belum berjalan sesuai dengan yang diinginkan, dimana Posyandu saat ini kurang dimanfaatkan oleh masyarakat sebagai pelayanan kesehatan hal ini dapat dilihat dari persentase cakupan balita yang ditimbang (D/S) pada tahun 2009 sebesar 69\% lebih kecil dari target yang ditetapkan yaitu $80 \%$ dan menurun ditahun

http://jurnalilmiah.stikescitradelima.ac.id/index.php/JI Vol.3,No.1, Juli 2019 
2010 menjadi 65\% lebih kecil dari target yang ditetapkan yaitu $85 \%$. Rendahnya pemanfaatan posyandu dapat disebabkan karena peran kader Posyandu Kurang aktif dalam mengajak sasaran/orang tua dalam memanfaatkan Posyandu. Jumlah kader aktif yang hadir minimal 7 kali dalam satu tahun terakhir dalam kegiatan Posyandu seperti penyuluhan, menimbang, pencatatan, dan pengisian KMS tahun 2009 hanya sebesar 65\%, dan tahun 2010 menurun menjadi 53\% (Profil

Puskesmas Sukamaju, 2010).

Hasil study pendahuluan yang peneliti lakukan pada tanggal 11 Maret 2011 di 2 Posyandu Puskesmas Sukamaju Bandar Lampung belum berjalan secara optimal, hasil wawancara menurut pepelaksanaan tugas kesehatan kegiatan posyandu lebih banyak dikerjakan oleh pepelaksanaan tugas Puskesmas terutama dalam memberikan pelayanan dimana pelaksanaan tugas kader hanya terfokus pada pembinaan dan pencatatan yang sama. Berdasarkan data yang diperoleh dari Puskesmas Sukamaju Tahun 2010, kader posyandu yang memiliki pendidikan terakhir SD yaitu sebesar 12 orang, SMP yaitu 48 orang dan SMA 13 orang. Kader Posyandu yang pernah mengikuti pelatihan posyandu Sebanyak 41 orang dan 32 orang belum pernah mengikuti pelatihan. Diketahui faktor - faktor yang berhubungan dengan pelaksanaan tugas kader Kesehatan dalam kegiatan Posyandu di Wilayah kerja Puskesmas Sukamaju

Teluk Betung Barat Bandar Lampung tahun 2011.

\section{METODE}

Jenis penelitian yang digunakan dalam penelitian ini adalah analitik yaitu jenis penelitian yang mencari hubungan antar variable (Notoatmodjo, 2005).

Penelitian ini akan dilaksanakan di Dusun Serba Jadi 2 Desa Pemanggilan Kecamatan Natar Bandar Lampung tahun 2011.

Rancangan dalam penelitian ini menggunakan desain pendekatan cross sectional yaitu desain penelitian yang bertujuan untuk mencari hubungan antara faktor resiko dengan efek pengamatan atau observasi antar variabel dilakukan secara bersamaan (Notoatmodjo,
2005). Desain cross sectional dalam penelitian ini digunakan untuk mengetahui faktor - faktor yang berhubungan dengan kurangnya peran serta kader kesehatan dalam kegiatan Posyandu Wilayah kerja Puskesmas Sukamaju Teluk Betung Barat Bandar Lampung tahun 2011.Populasi adalah keseluruhan objek penelitian atau objek yang akan diteliti (Notoadmojo,2005). Adapun yang menjadi populasi dalam penelitian ini adalah seluruh kader Posyandu Wilayah kerja Puskesmas Sukamaju Teluk Betung Barat Bandar Lampung tahun 2011 sebesar 45 kader. Sampel adalah sebagian yang diambil dari keseluruhan objek yang diteliti dan dianggap mewakili seluruh populasi (Notoadmojo, 2005). Menurut Arikunto (2006) jika populasi kurang dari sama dengan 100 maka lebih baik diambil seluruhnya. Karena populasi dalam penelitian ini 100 maka

menggunakan total populasi yang berarti seluruh kader Posyandu Wilayah kerja Puskesmas Sukamaju Teluk Betung Barat Bandar Lampung sebesar 45 orang diambil sebagai subjek penelitian.

\section{HASIL}

\section{Analisa Univariat}

Analisa yang digunakan dalam penelitian ini adalah analisa univariat yang dilakukan pada tiap variabel dalam bentuk tabel distribusi frekuensi responder berdasarkan Pelaksanaan tugas Kader, pendidikan, pelatihan dan pengetahuan.

Hasil penelitian terhadap 85 responden didapat:

\section{a. Pelaksanaan tugas Kader}

Tabel 4.1

Distribusi frekuensi Pelaksanaan tugas

Kader Posyandu di wilayah Kerja

Puskesmas Sukamaju Teluk Betung Barat

Bandar Lampung

Tahun 2011

\begin{tabular}{|l|l|l|}
\hline $\begin{array}{l}\text { Pelaksanaan tugas } \\
\text { kader }\end{array}$ & $\mathbf{n}$ & $\mathbf{\%}$ \\
\hline Kurang baik & 48 & 56,5 \\
\hline baik & 37 & 43,5 \\
\hline Total & 85 & 100,0 \\
\hline
\end{tabular}

http://jurnalilmiah.stikescitradelima.ac.id/index.php/JI

Vol.3,No.1, Juli 2019 
Berdasarkantabel 4.1 diatas dapat diketahui bahwa distribusi frekuensi respondenberdasarkan Pelaksanaan tugas kader lebih tinggi pada kategori kurang baik sebesar48 orang $(56,5 \%)$.

\section{b. Pendidikan}

Tabel 4.2

Distribusi frekuensi pendidikan Kader Posyandu di wilayah Kerja Puskesmas Sukamaju Teluk Betung Barat Bandar Lampung

Tahun 2011

\begin{tabular}{|l|l|l|}
\hline Pendidikan & n & \% \\
\hline Rendah & 53 & 62,4 \\
\hline Tinggi & 32 & 37,6 \\
\hline Total & 85 & 100,0 \\
\hline
\end{tabular}

Berdasarkan tabel 4.2 diatas dapat diketahui bahwa distribusi frekuensi responden berdasarkan pendidikan kader lebih tinggi pada kategori rendah sebesar 53 orang $(62,4 \%)$.

\section{c. Pelatihan}

Tabel 4.3

Distribusi frekuensi pelatihan Kader Posyandu di wilayah

Kerja Puskesmas Sukamaju Teluk Betung Barat

\section{Bandar Lampung Tahun 2011}

\begin{tabular}{|l|l|l|}
\hline Pelatihan & n & \% \\
\hline Tidak pernah & 57 & 62,4 \\
\hline Pernah & 28 & 37,6 \\
\hline Total & 85 & 100,0 \\
\hline
\end{tabular}

Berdasarkan tabel 4.3 diatas dapat diketahui bahwa distribusi frekuensi responden berdasarkan pelatihan kader lebih tinggi pada kategori tidak pernah sebesar 57 orang $(62,4 \%)$.

\section{d. Pengetahuan}

Tabel 4.4

Distribusi frekuensi pengetahuan Kader Posyandu di wilayah

Kerja Puskesmas Sukamaju Teluk Betung Barat

Bandar Lampung Tahun 2011

\begin{tabular}{|l|l|l|}
\hline Pengetahuan & n & \% \\
\hline
\end{tabular}

\begin{tabular}{|l|l|l|}
\hline Kurang baik & 56 & 65,9 \\
\hline baik & 29 & 43,5 \\
\hline Total & 85 & 100,0 \\
\hline
\end{tabular}

Berdasarkan tabel 4.4 diatas dapat diketahui bahwa distribusi frekuensi responden berdasarkan pengetahuan lebih tinggi pada kategori kurang baik sebesar 56 orang $(65,9 \%)$.

\section{Analisa Bivariat}

Analisa Bivariat chi square untuk mengetahui faktor faktor yang berhubungan dengan pelaksanaan tugas kader kesehatan dalam kegiatan Posyandu di Wilayah kerja Puskesmas Sukamaju Teluk Betung Barat Bandar Lampung tahun 2011. Hasil analisa bivariat ditampilkan dalam bentuk silang berikut ini:

a.Hubungan antara pendidikan dengan pelaksanaan tugaskader

\section{Tabel 4.5}

Hubungan pendidikan dengan Pelaksanaan tugaskader Posyandu

di wilayah Kerja Puskesmas Sukamaju Teluk Betung Barat

Bandar Lampung

Tahun 2011

\begin{tabular}{|c|c|c|c|c|c|c|c|c|}
\hline \multirow[t]{3}{*}{$\begin{array}{l}\text { Pendid } \\
\text { ikan }\end{array}$} & \multicolumn{4}{|c|}{$\begin{array}{l}\text { Pelaksanaan } \\
\text { tugas kader }\end{array}$} & \multirow[t]{3}{*}{$\mathrm{N}$} & \multirow[t]{3}{*}{$\%$} & \multirow{3}{*}{$\begin{array}{l}\mathrm{P} \\
\text { Val } \\
\text { ue }\end{array}$} & \multirow[t]{3}{*}{ OR } \\
\hline & \multicolumn{2}{|c|}{$\begin{array}{l}\text { Kuran } \\
\text { g baik }\end{array}$} & \multicolumn{2}{|c|}{ Baik } & & & & \\
\hline & $\mathrm{n}$ & $\%$ & $\mathrm{n}$ & $\%$ & & & & \\
\hline Renda & 3 & 67 & 1 & 32 & 5 & 1 & 0,0 & 3,5 \\
\hline $\mathrm{h}$ & 6 & ,9 & 7 & ,1 & 3 & $\begin{array}{l}0 \\
0\end{array}$ & 12 & 29 \\
\hline Tinggi & $\begin{array}{l}1 \\
2\end{array}$ & $\begin{array}{l}37 \\
, 5\end{array}$ & $\begin{array}{l}2 \\
0\end{array}$ & $\begin{array}{l}62 \\
, 5\end{array}$ & $\begin{array}{l}3 \\
2\end{array}$ & $\begin{array}{l}1 \\
0 \\
0\end{array}$ & & \\
\hline $\mathrm{N}$ & $\begin{array}{l}4 \\
8\end{array}$ & $\begin{array}{l}56 \\
, 5\end{array}$ & $\begin{array}{l}3 \\
7\end{array}$ & $\begin{array}{l}43 \\
, 5\end{array}$ & $\begin{array}{l}8 \\
5\end{array}$ & $\begin{array}{l}1 \\
0 \\
0\end{array}$ & & \\
\hline
\end{tabular}

Berdasarkan tabel 4.5 dapat diketahui dari 53 responden dengan pendidikan rendah ada sebanyak 36 orang $(67,9 \%)$ memiliki pelaksanaan tugas kurang baik dalam penyelenggaraan Posyandu, sedangkan pada responden dengan pendidikan tinggi dari 32 orang ada sebanyak 20 orang $(62,5 \%)$ 
memiliki Pelaksanaan tugas baik dalarn penyelenggaraan Posyandu. Hasil uji statistik chi square didapat nilai $\mathrm{p}$ valuce $<\alpha,(0,012<$ $0,05)$. Artinya Ho ditolak dapat disimpulkan ada hubungan pendidikan kader dengan pelaksanaan tugas kader posyandu di wilayah kerja Puskesmas Sukamaju

Teluk Betung Barat Bandar Lampung tahun 2011.OR didapat 3,529 yang berarti respoden dengan pendidikan rendah berpeluang 3,529 kali lebih besar untuk memiliki pelaksanan tugas kurang baik dibandingkan responden dengan pendidikan tinggi.

\section{b. Hubungan antara pengetahuan dengan pelaksanaan tugaskader}

Tabel 4.6

Hubungan pengetahuan kader dengan Pelaksanaan tugaskader Posyandu wilayah Kerja Puskesmas Sukamaju Teluk Betung Barat

Bandar Lampung Tahun 2011

\begin{tabular}{|c|c|c|c|c|c|c|c|c|}
\hline \multirow[t]{3}{*}{$\begin{array}{l}\text { Penget } \\
\text { ahuan }\end{array}$} & \multicolumn{4}{|c|}{$\begin{array}{l}\text { Pelaksanaan } \\
\text { tugas kader }\end{array}$} & \multirow[t]{3}{*}{$\mathrm{N}$} & \multirow[t]{3}{*}{$\%$} & \multirow{3}{*}{$\begin{array}{l}\mathrm{P} \\
\text { Val } \\
\text { ue }\end{array}$} & \multirow[t]{3}{*}{$\overline{\mathrm{OR}}$} \\
\hline & \multicolumn{2}{|c|}{$\begin{array}{l}\text { Kuran } \\
\text { g baik }\end{array}$} & \multicolumn{2}{|c|}{ Baik } & & & & \\
\hline & $\mathrm{n}$ & $\%$ & $\mathrm{n}$ & $\%$ & & & & \\
\hline \multirow[t]{2}{*}{ Rendah } & 4 & 76 & 1 & 23 & 5 & 1 & \multirow{6}{*}{$\begin{array}{l}0,0 \\
00\end{array}$} & \multirow{6}{*}{$\begin{array}{l}15 \\
877\end{array}$} \\
\hline & 3 & ,8 & 3 & ,2 & 6 & $\begin{array}{l}0 \\
0\end{array}$ & & \\
\hline \multirow[t]{2}{*}{ Tinggi } & 5 & 17 & 2 & 82 & 2 & 1 & & \\
\hline & &, 2 & 4 &, 8 & 9 & 0 & & \\
\hline \multirow[t]{2}{*}{$\mathrm{N}$} & 4 & 56 & 3 & 43 & 8 & 1 & & \\
\hline & 8 &, 5 & 7 &, 5 & 5 & $\begin{array}{l}0 \\
0\end{array}$ & & \\
\hline
\end{tabular}

Berdasarkan tabel 4.6 dapat diketahui dari 56 responden dengan pengetahuan kurang baik ada sebanyak 43 orang $(76,8 \%)$ memiliki Pelaksanaan tugas kurang baik dalam penyelenggaraan Posyandu, sedangkan pada responden dengan pengetahuan baik dari 29 orang ada sebanyak 24 orang $(82,8 \%)$ memiliki Pelaksanaan tugas baik dalam penyelenggaraan Posyandu. Hasil uji statistik chi square didapat nilai $\mathrm{p}$ value $<$ dari $\alpha(0,000$ $<0,05)$. Artinya Ho ditolak dapat disimpulkan ada hubungan pengetahuan kader dengan Pelaksanaan tugas kader posyandu di wilayah kerja Puskesmas Sukamaju Teluk Betung
Barat Bandar Lampung tahun 2011. OR didapat 15,877 yang berarti respoden dengan pendidikan pengetahuan kurang baik berpeluang 15,877 kali lebih besar untuk memiliki Pelaksanaan tugas kurang baik dibandingkan responden dengan pengetahuan baik.

e.Hubungan antara pelatihan dengan pelaksanaan tugas kader

Tabel 4.7

Hubungan pelatihan kader dengan Pelaksanaan tugas kader Posyandu

di wilayah Kerja Puskesmas Sukamaju Teluk Betung Barat

Bandar Lampung Tahun 2011

\begin{tabular}{|c|c|c|c|c|c|c|c|c|}
\hline \multirow[t]{3}{*}{$\begin{array}{l}\text { Pelati } \\
\text { han }\end{array}$} & \multicolumn{4}{|c|}{$\begin{array}{l}\text { Pelaksanaan } \\
\text { tugas kader }\end{array}$} & \multirow[t]{3}{*}{$\mathrm{N}$} & \multirow[t]{3}{*}{$\%$} & \multirow{3}{*}{$\begin{array}{l}\text { P } \\
\text { Val } \\
\text { ue }\end{array}$} & \multirow[t]{3}{*}{ OR } \\
\hline & \multicolumn{2}{|c|}{$\begin{array}{l}\text { Kuran } \\
\text { g baik }\end{array}$} & \multicolumn{2}{|c|}{ Baik } & & & & \\
\hline & $\mathrm{n}$ & $\%$ & $\mathrm{n}$ & $\%$ & & & & \\
\hline \multirow{2}{*}{$\begin{array}{l}\text { Rend } \\
\text { ah }\end{array}$} & 3 & 68 & 1 & 31 & 5 & 10 & \multirow{6}{*}{$\begin{array}{l}0,0 \\
03\end{array}$} & \multirow{6}{*}{$\begin{array}{l}4,5 \\
74\end{array}$} \\
\hline & 9 & ,4 & 8 & ,6 & 7 & 0 & & \\
\hline Tingg & 9 & 32 & 1 & 67 & 2 & 10 & & \\
\hline $\mathrm{i}$ & & ,1 & 9 & ,9 & 8 & 0 & & \\
\hline \multirow[t]{2}{*}{$\mathrm{N}$} & 4 & 56 & 3 & 43 & 8 & 10 & & \\
\hline & 8 &, 5 & 7 &, 5 & 5 & 0 & & \\
\hline
\end{tabular}

Berdasarkan tabel 4.7 dapat diketahui dari 57 responden yang tidak pernah mengikuti pelatihan ada sebanyak 39 orang $(68,4 \%)$ memiliki Pelaksanaan tugas kurang baik dalam penyelenggaraan Posyandu, sedangkan pada responden yang pernah mengikuti pelatihan dari 28 orang ada sebanyak 19 orang $(67,9 \%)$ memiliki Pelaksanaan tugas baik dalam penyelenggaraan Posyandu. Hasil uji statistik chi square didapat nilai $\mathrm{p}$ value $<$ dari $\alpha(0,003$ $<0,05)$. Artinya Ho ditolak dapat disimpulkan ada hubungan pelatihan kader dengan Pelaksanaan tugaskader posyandu di wilayah kerja Puskesmas Sukamaju Teluk Betung Barat Bandar Lampung tahun 2011. OR didapat 4,574 yang berarti responden yang tidak pemah mengikuti pelathan berpeluang 4,574 kali lebih besar untuk memiliki Pelaksanaan tugaskurang baik dibandingkan responden responden yang pemah mengikuti pelatihan.

http://jurnalilmiah.stikescitradelima.ac.id/index.php/JI Vol.3,No.1, Juli 2019 


\section{PEMBAHASAN}

Berdasarkan hasil penelitian pada tabel 4.5 dapat diketahui hasil uji statistikchi square didapat nilai $\mathrm{p}$ value $<$ dari $\alpha(0,012<0,05)$, Artinya Ho ditolakdapat disimpulkan ada hubungan pendidikan kader dengan pelaksanaantugaskader posyandu di wilayah kerja Puskesmas Sukamaju Teluk BetungBarat Bandar Lampung tahun 2011. OR didapat 3,529 yang berarti respodendengan pendidikan rendah berpeluang 3,529 kali lebih besar untuk memiliki pelaksanaan tugaskurang baik dibandingkan responden dengan pendidikan tinggi.

Hasil ini sejalan dengan teori Muhaimin (2004) yang menyatakan orangdengan pendidikan formal yang lebih tinggi cenderung akan mempunyaipengetahuan yang lebih tinggi dibandingkan dengan orang yang mempunyaitingkat pendidikan formal yang lebih rendah, karena akan lebih mampu dan mudah memahami arti dan pentingnya kesehatan dan gangguan-gangguankesehatan yang mungkin terjadi. Pengetahuan akan mempengaruhi pola fikirseseorang, selain itu kemampuan kognitif membentuk cara fikir seseorang,meliputi kemampuan untuk mengerti faktor-faktor yangberpengaruh dalampraktek kesehatan personal, informasi baru dan penerimaan konsep baru.

\section{SIMPULAN}

Pelaksana tugas kader lebih tinggi pada kategori kurang baik.

Pendidikan kader lebih tinggi pada kategori rendah. Pelatihan kader lebih tinggi pada kategori tidak pernah. Pengetahuan kader lebih tinggi pada kategori kurang baik. Ada hubungan yang bermakna antara pendidikan dengan Pelaksanaan tugaskader Posyandu.

Ada hubungan yang bermakna antara pengetahuan dengan Pelaksanaan tugasKader Posyandu. Ada hubungan yang bermakna antara pelatihan dengan Pelaksanaan tugas kader Posyandu.
Arikunto, S. Edisi revisi 2010. Prosedur Penelitian Suatu Pendekatan Praktek. Jakarta: Rineka Cipta

BKKBN, 2008. Buku Panduan Kader Posyandu. Jakarta:Jakarta.

Depkes Rl, 2004. Pedoman kegiatan Kader Posyandu. Jakarta.

Depkes RI, 2006. Modul Pelatihan Peningkatan Peran Serta Kader Dalam Kegiatan Posyandu.Jakarta.

Depkes 2009, Kematian Maternal dan Neonatal.dalam www.depkes.go.id. Diakses tanggal 16 Maret 2011

Dikbud, 2008. Pendidikan di indonesia. www.dikbud.go.id diakses tanggal 14 Maret 2011

Dinkes Kabupaten Way Kanan, 2010.Profil Kesehatan Way Kanan. Way Kanan

Gany, Dessler. 2004. Manajemen Sumber Daya Manusia. Yogyakarta. Graha Ilmu

Hadi, Sutrisno. 2002. Metodologi Riset, Yogyakarta. Andi Offset

Hastono, 2007. Analisis Data. Jakarta. FKMUI

Hegar, Badriul, 2009. Angka Kematian Balita (Akaba) dalam www.bkkbn.com Diakses tanggal 14 Maret 2011

Hemas, 2005.Faktor yang mempengaruhi keaktifan kader Posyandu. Jakarta: Aneka Karya

Mangkunegara, Anwar Prabu. 2008. Evaluasi Kinerja Sumber Daya Manusia Bandung. Jakarta. PT. Refika Aditama

Notoatmojo, Soekidjo. 2003. Pendidikan dan perilaku Kesehatan. Jakarta. Rineka Cipta

Notoatmojo, Soekidjo.2005. Metodologi Penelitian Kesehatan. Jakarta: Rineka Cipta

Wijaya, Rafika Dora 2005.Insiden kematian Persalinan dalam www.mulia.com diakses tanggal 16 Januari 2011

Yoel, Chairul, 2007. Anak meninggal setiap jam di Indonesia. Dalam www.hariansib.com, Diakses tanggal 17 Maret 2011.

\section{DAFTAR PUSTAKA}

